Boiler Efficiency and Safety 
Some potential savings from following

advice in this book

- First, enhanced safety saves life and health

- Savings of 5 to 10 per cent on fuel costs are often possible at little or no cost

- Savings of up to 30 per cent on fuel costs may be possible by using new steamgenerating or steam-using equipment

- Target boiler efficiency with new package boilers can be up to 85 per cent at maximum continuous rating

- Off-line time can drop drastically, giving production continuity and reduced labour costs

- Repair costs can drop by thousands of pounds a year

Only you can achieve savings of this kind at your plant, but the information in this book can help. 


\section{Boiler Efficiency and Safety}

\section{A Guide for Managers, Engineers and Operators responsible for Small Steam Boilers}

Edited by

W. S. Robertson

Contributors

H. M. Ashton

G. Datschefski

A. J. R. Isaacs

C. S. Macdonald

W. S. Robertson

K. C. Salooja

E. G. White 
(C) Esso Petroleum Company, Limited 1981

Softcover reprint of the hardcover 1st edition 1981

All rights reserved. No part of this publication may be reproduced or transmitted, in any form or by any means, without permission.

First published 1981 by

THE MACMILLAN PRESS LTD

London and Basingstoke

Associated companies in Delhi Dublin

Hong Kong Jöhannesburg Lagos Melbourne

New York Singapore and Tokyo

Typeset in 10/12 Press Roman by

STYLESET LIMITED

Salisbury . Wiltshire

ISBN 978-1-349-04792-5 ISBN 978-1-349-04790-1 (eBook)

DOI 10.1007/978-1-349-04790-1

This book is sold subject to the standard conditions of the

Net Book Agreement. 


\section{Contents}

Preface vii

1 Safety 1

2 Types and selection of fuel oils $\quad 6$

3 Combustion processes and monitoring 13

4 Combustion in practice $\quad 24$

5 Water treatment $\quad 39$

$\begin{array}{lll}6 & \text { Boiler operations } & 56\end{array}$

$\begin{array}{lll}7 & \text { Maintenance } & 71\end{array}$

$\begin{array}{lll}8 & \text { Efficient use of steam } & 109\end{array}$

9 Training courses and material $\quad 121$

$\begin{array}{lr}\text { Index } & 137\end{array}$ 


\section{Preface}

This book covers practical steps to achieve fuel - and money - savings in one specific area: for package steam boilers of up to about $10 \mathrm{MW}$ output. The authors know its content achieves savings - they have achieved them in their own organisation.

The book is written principally for managers responsible for automatic steam boilers, and for supervisors and operators who run them. It gives managers the background data that they need to ensure their equipment is operated at maximum efficiency. It also gives operators the basic information they need to carry out efficient boiler operation. The book is not primarily intended for professional engineers: they are likely to know it all already, although some may appreciate a reminder of a few basic points.

The content of the book springs from a programme on boiler efficiency and safety introduced in Esso Petroleum Company marketing plants. That programme for plant managers and for operators saved $£ 60000$ in fuel costs in its first year. The Boiler Efficiency and Safety Training programme was later made generally available to industry as an audio-visual presentation on filmstrip/tape and on video.

However, since audiovisual techniques are not always applicable, this book has been written, mainly by those involved in the original programme, to expand on the information in the programme and to make it more widely available.

The book begins with a discussion of vital safety factors. It then briefly covers the types and selection of oil fuels. Although the book as a whole uses oil-fired boilers as examples, only chapter 2 on types and selection is exclusively concerned with oil fuel - much of the remainder applies equally to gas firing and, to a lesser extent, to solid-fuel firing.

The book deals in some detail with the theory and practice of combustion and of water treatment. This is followed by a chapter on boiler operation and a comprehensive chapter on maintenance. The chapter on steam use stresses the important but sometimes overlooked point that savings here can be many times as great as savings in steam generation. Finally, there is a chapter on training courses and information for operators and managers.

The authors gratefully acknowledge permission from Esso Petroleum Company, Limited to publish their contributions. However, responsibility for the content and for any errors that may have persisted in it is theirs alone. 


\section{Acknowledgements}

The authors gratefully acknowledge provision of illustrations by the following organisations

Taylor Analytics

NEI Thompson Cochran Ltd

University of Leicester audio visual unit

Bestobell Mobrey Ltd

Nu-way Heating Plants Ltd

Hamworthy Engineering Ltd

Spirax Sarco Ltd 